\title{
FAKTOR-FAKTOR YANG MEMENGARUHI TINGKAT AKURASI RENCANA PENARIKAN DANA (RPD) HARIAN SATUAN KERJA KEMENTERIAN/LEMBAGA
}

\author{
Tri Angga Sigit \\ Direktorat Jenderal Perbendaharaan \\ Alamat Korespondensi: hanif643@gmail.com
}

\begin{abstract}
This study aims to determine the effects of the human resource quality, the SAS (Unit Application System) performance, the infrastructure completeness, rewards and punishments, as well as dispensations on the accuracy level of Daily Cash Withdrawal Planning (RPD) compiled by work units of ministries and national institutions. Using the binary logistic regression method, the study was conducted by distributing questionnaires to all work units that had submitted the 2017 Daily RPD to KPPN Jakarta II. The results reveal that all variables simultaneously have significant influence on the accuracy level of Daily RPD. In addition, as partial variables, both the human resource quality and the SAS application performance positively and significantly affect the accuracy level of Daily RPD.
\end{abstract}

\section{KATA KUNCI:}

RPD Harian, Satuan Kerja Kementerian/Lembaga, Perencanaan Kas Pemerintah Pusat

\section{ABSTRAK}

Penelitian ini membahas pengaruh variabel Kualitas SDM, Kinerja Aplikasi SAS, Kelengkapan Sarana dan Prasarana, Sistem Reward and Punishment dan Dispensasi terhadap Tingkat Akurasi RPD Harian yang disusun oleh satker kementerian negara/lembaga (K/L). Penelitian ini dilakukan dengan menyebarkan kuisioner terhadap seluruh satker K/L yang menyampaikan RPD Harian pada Tahun Anggaran 2017 dalam lingkup KPPN Jakarta II. Metode penelitian menggunakan Regresi Logistik Binary. Hasil penelitian menunjukkan bahwa secara simultan seluruh variabel berpengaruh signifikan terhadap Tingkat Akurasi RPD Harian. Secara parsial, Kualitas SDM dan Kinerja Aplikasi SAS berpengaruh secara positif dan signifikan terhadap Tingkat Akurasi RPD Harian.

KLASIFIKASI JEL:

E62

\section{CARA MENGUTIP:}

Sigit. T. A. (2019). Faktor-faktor yang memengaruhi tingkat akurasi rencana penarikan dana (RPD) harian satuan kerja kementerian/lembaga. Indonesian Treasury Review, 4(2), 145-161. 


\section{PENDAHULUAN}

\subsection{Latar Belakang}

Perencanaan Kas Pemerintah Pusat adalah penyusunan proyeksi penerimaan negara, proyeksi belanja negara dan proyeksi saldo kas dalam periode tertentu dalam rangka pelaksanaan APBN. Perencanaan kas mulai disadari urgensinya sejak diterbitkannya Undang-undang Nomor 1 Tahun 2004 tentang Perbendaharaan Negara. Dengan kondisi sumber daya yang dimiliki masih sangat terbatas untuk membiayai pembangunan, pemerintah perlu mengelola likuiditasnya dengan mengalokasikan sumber daya secara akurat. Dengan melakukan perencanaan kas, pemerintah juga dapat memprediksi ketersediaan kas pada masa yang akan datang, baik ketika terjadi kekurangan kas maupun kelebihan kas.

Laporan Perencanaan Kas Pemerintah Pusat disusun dengan memadukan perencanaan kas yang berasal dari internal Kementerian Keuangan yaitu Komite Assets Liabilities Management (ALM), Tim Cash Planning Information Network (CPIN) dan data historis serta perencanaan kas yang berasal dari K/L. Pemerintah melalui Menteri Keuangan terus melakukan upaya untuk meningkatkan kualitas Laporan Perencanaan Kas Pemerintah Pusat agar menjadi lebih baik, terutama terkait dengan perencanaan kas yang dilaksanakan oleh satker K/L. Diterbitkannya Peraturan Menteri Keuangan (PMK) Nomor 277/PMK.05/2014 tentang Rencana Penarikan Dana, Rencana Penerimaan Dana, dan Perencanaan Kas pada tanggal 31 Desember 2014 merupakan langkah nyata Menteri Keuangan untuk memperbaiki implementasi penyusunan proyeksi pengeluaran satker K/L yang masih banyak mengalami hambatan pada saat implementasi peraturan sebelumnya yaitu PMK Nomor 192/PMK.05/2009 tentang Perencanaan Kas.

Berdasarkan PMK Nomor 277/PMK.05/2014, laporan Perencanaan Kas Pemerintah Pusat disusun secara bertingkat mulai dari satker K/L sampai dengan Direktorat Pengelolaan Kas Negara (PKN) Direktorat Jenderal Perbendaharaan. Satker K/L diwajibkan membuat kalender kegiatan untuk satu tahun anggaran dan menyusun Rencana Penarikan Dana (RPD) Harian untuk proyeksi pengeluaran yang masuk dalam kriteria transaksi besar. Transaksi besar adalah kriteria nilai pengeluaran yang diatur dalam PMK 277/PMK.05/2014 dimana jika nilai tersebut direalisasikan maka akan memberikan pengaruh yang signifikan terhadap posisi kas pemerintah. Jika satker K/L mengajukan SPM yang masuk dalam kriteria transaksi besar tanpa mengajukan RPD Harian maka satker K/L harus mengajukan dispensasi kepada Kepala Kantor Pelayanan Perbendaharaan Negara (KPPN). Seluruh data RPD Harian yang diajukan oleh satker K/L selanjutnya dikonsolidasikan menjadi RPD Harian Tingkat KPPN dan dikirimkan kepada Direktorat PKN setiap hari paling lambat pukul 22.00 WIB.

\subsection{Perumusan Masalah}

Berdasarkan hasil monitoring dan evaluasi penyampaian RPD Harian yang dilakukan secara rutin oleh Direktorat PKN pada KPPN di seluruh Indonesia, masih ditemukan berbagai indikasi bahwa implementasi kebijakan penyusunan dan penyampaian RPD Harian oleh satker K/L masih mengalami berbagai permasalahan terutama terkait dengan tingkat akurasi RPD Harian dimana masih terjadi deviasi RPD Harian yang cukup tinggi. Deviasi merupakan perbedaan antara proyeksi pengeluaran pada RPD Harian dengan realisasinya dalam bentuk Surat Perintah Membayar (SPM) dan diukur dalam satuan persen. Tingginya tingkat deviasi RPD Harian satker K/L menyebabkan RPD Harian Tingkat KPPN menjadi tidak akurat sehingga dapat berpengaruh terhadap tingkat akurasi laporan Perencanaan Kas Pemerintah Pusat secara keseluruhan.

\section{Gambar 1. Tingkat Deviasi RPD Harian} Tahun 2016

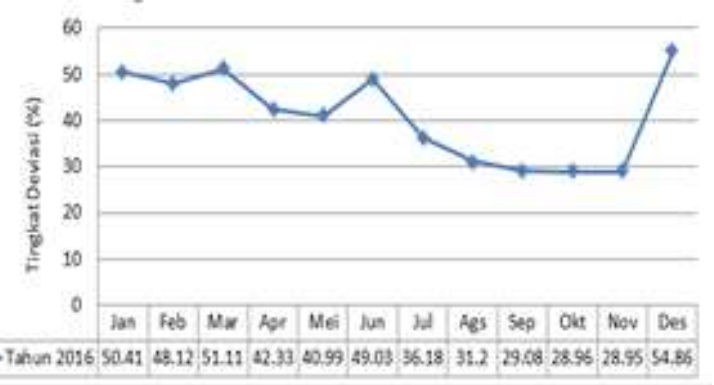

(Sumber: data diolah)

Dari data tersebut dapat diketahui bahwa tingkat deviasi RPD Harian secara nasional masih sangat tinggi. Hal ini menunjukkan bahwa penyusunan RPD Harian oleh satker K/L masih belum memiliki tingkat akurasi yang baik. Tingginya tingkat deviasi tersebut menyebabkan laporan Perencanaan Kas Pemerintah Pusat yang dihasilkan menjadi tidak akurat sehingga dapat memberikan informasi yang tidak tepat dalam pengambilan keputusan terkait pengelolaan likuiditas Pemerintah. Ketidakakuratan dalam pengambilan keputusan terkait pengelolaan likuiditas pada akhirnya dapat menyebabkan timbulnya berbagai biaya yang tidak perlu dalam 
memenuhi berbagai kewajiban likuiditas pemerintah.

Penyusunan RPD Harian oleh satker K/L yang masih belum berjalan dengan baik juga ditandai dengan tingginya pengajuan dispensasi oleh satker K/L kepada Kepala KPPN. Dengan adanya dispensasi dari Kepala KPPN tersebut, satker K/L dapat mengajukan SPM yang masuk kriteria transaksi besar tanpa didahului dengan pengajuan RPD Harian. Untuk tahun 2016 jumlah dispensasi yang diajukan oleh satker K/L mencapai 9.935 buah dengan nilai total mencapai Rp109,176 triliun. Tingginya jumlah dispensasi tersebut mengindikasikan masih terjadi berbagai permasalahan pada satker K/L sehingga tidak dapat memenuhi kewajiban menyampaikan RPD Harian kepada KPPN dengan baik.

\subsection{Penelitian Sebelumnya}

Penelitian ini dibangun dengan kerangka pemikiran yang berasal dari hasil penelitian dan literatur terdahulu yang terkait dengan perencanaan kas pemerintah. Muthohar (2012) melakukan penelitian terhadap efektivitas penyusunan proyeksi belanja yang disusun satker K/L berdasarkan implementasi PMK Nomor 192/PMK.05/2009. Muthohar (2012) menyebutkan bahwa secara teoritis data perencanaan kas yang disusun oleh satker K/L seharusnya merupakan data yang paling dapat dipertanggungjawabkan keakuratannya karena berasal dari lingkup satker K/L sendiri. Dalam penelitiannya, Muthohar (2012) menyimpulkan bahwa kualitas sumber daya manusia (SDM), kualitas aplikasi dan sistem reward and punishment berpengaruh positif terhadap efektivitas proyeksi belanja satker K/L. Mu (2006) menyebutkan bahwa perencanaan kas pemerintah yang efektif harus didukung adanya SDM yang berkualitas dan sistem teknologi informasi yang tangguh. Lienert (2009) menambahkan pentingnya faktor dukungan aplikasi yang berteknologi tinggi dan adanya sistem reward and punishment agar perencanaan kas pemerintah dapat berjalan dengan efektif.

Berdasarkan penelitian dan literatur terdahulu tersebut, penulis menyusun konstruksi penelitian dengan mengidentifikasi bahwa terdapat 5 (lima) faktor yang memengaruhi tingkat akurasi RPD Harian satker K/L yaitu kualitas SDM, kinerja aplikasi Sistem Aplikasi Satker (SAS), kelengkapan sarana dan prasarana, sistem reward and punishment dan dispensasi. Kebijakan dispensasi baru mulai diterapkan setelah diimplementasikanya PMK Nomor 277/PMK.05/2014. Dalam penelitian ini penulis menganalisis kelima faktor tersebut dan bagaimana pengaruhnya terhadap tingkat akurasi RPD Harian yang disusun oleh satker K/L setelah mulai diimplementasikannya PMK Nomor 277/PMK.05/2014.

\section{KERANGKA TEORI DAN PENGEMBANGAN HIPOTESIS}

Dalam bagian ini dijelaskan berbagai teori dan hipotesis yang dibangun untuk menjelaskan landasan penulis dalam melakukan penelitian.

\subsection{Manajemen Kas Pemerintah}

Dalam Undang-Undang APBN yang ditetapkan setiap tahun, struktur APBN terdiri dari tiga unsur utama yaitu : (1) Pendapatan Negara, terdiri dari Penerimaan Perpajakan, Penerimaan Negara Bukan Pajak dan Hibah, (2) Belanja Negara, terdiri dari Belanja Pemerintah Pusat dan Transfer Ke Daerah dan Dana Desa, serta (3) Pembiayaan. Adanya pembiayaan pada APBN disebabkan pemerintah masih menerapkan kebijakan anggaran defisit dimana seluruh pendapatan negara masih belum mencukupi untuk mendanai seluruh belanja negara.

Menurut Rahardja dan Manurung (2004), defisit anggaran terjadi karena pengeluaran pemerintah direncanakan lebih besar dari penerimaan pemerintah dengan tujuan untuk menstimulasi pertumbuhan ekonomi. Sukirno (1994) menyebutkan ada dua penyebab yang mengharuskan suatu negara harus mencapai pertumbuhan ekonominya yaitu untuk menciptakan lapangan pekerja bagi penduduknya yang setiap saat bertambah dan untuk menaikkan tingkat kemakmuran masyarakat. Muthohar (2012) menjelaskan bahwa adanya defisit dan pembiayaan menunjukkan pemerintah selaku bagian dari perekonomian dan menjadi pelaku ekonomi juga mengalami masalah kelangkaan (scarcity).

Undang-undang Nomor 17 Tahun 2003 tentang Keuangan Negara memberikan batasan besar defisit pemerintah sebesar 3 persen dari Produk Domestik Bruto (PDB) Indonesia. Berbagai hal tersebut mendorong pemerintah untuk melakukan pembiayaan berupa pinjaman baik yang berasal dari dalam negeri maupun luar negeri. Menimbang bahwa sumber pendanaan pemerintah yang berasal dari pendapatan negara masih sangat terbatas dan kekurangannya masih ditutup dari pembiayaan maka setiap pengeluaran pemerintah harus dilakukan secara efektif dan efisien. Untuk itu diperlukan adanya 
suatu manajemen kas pemerintah yang profesional dan akuntabel.

Menurut $\mathrm{Mu}$ (2006), manajemen kas pemerintah adalah strategi dan seluruh proses terkait pengaturan arus kas pemerintah dalam jangka pendek di antara berbagai lembaga pemerintah dan antara pemerintah dengan sektor swasta. Storkey (2003) mendefinisikan manajemen kas pemerintah adalah memiliki sejumlah uang pada waktu dan tempat yang tepat untuk memenuhi kewajiban pemerintah dengan biaya yang paling menguntungkan.

Manajemen kas yang efektif menurut $\mathrm{Mu}$ (2006) dapat mencapai tujuan ideal yaitu: (1) menyediakan dana tepat waktu untuk membiayai pengeluaran pemerintah dan pembayaran utang, (2) menghindari munculnya biaya atas saldo kas menganggur dalam sistem perbankan, (3) meningkatkan penerimaan dari investasi kas yang menganggur (idle cash), dan (4) mengurangi dan mengendalikan berbagai risiko seperti refinancing, credit, roll over, dan market risks. Lienert (2009) menyebutkan bahwa tujuan dilakukannya manajemen kas pemerintah adalah untuk : (1) memastikan ketersediaan dana untuk membiayai pengeluaran yang jatuh tempo, (2) mengumpulkan semua penerimaan pada satu rekening, (3) melakukan pinjaman jika diperlukan dengan meminimalkan jumlah biaya bunga dari pinjaman, (4) optimalisasi idle cash, dan (5) mengelola risiko dengan investasi surplus hanya pada instrumen yang memiliki agunan yang memadai.

Dari berbagai pandangan tersebut dapat disimpulkan bahwa tujuan dari manajemen kas pemerintah meliputi berbagai aspek mulai dari penyediaan dana untuk membiayai belanja pemerintah, investasi atas adanya saldo idle cash, meminimalkan biaya pengelolaan kas pemerintah dan mengelola berbagai macam risiko fiskal dalam pengelolaan kas pemerintah.

Pelaksanaan manajemen kas pemerintah selama ini disimpulkan masih belum berjalan dengan maksimal. Williams (2004) menyebutkan bahwa manajemen kas di sektor pemerintahan masih belum mendapatkan perhatian baik oleh pemerintah sendiri, akademisi serta pihak terkait lainnya jika dibandingkan dengan manajemen hutang (debt management). Hal tersebut dikarenakan dampak yang ditimbulkan oleh manajemen kas lebih bersifat jangka pendek dan dapat lebih cepat diperbaiki dampaknya jika dibandingkan dengan manajemen hutang yang dapat memberikan dampak besar terhadap perekonomian dalam jangka panjang.

\subsection{Perencanaan Kas Pemerintah}

$\mathrm{Mu}$ (2006) menekankan bahwa perencanaan kas (cash flow forecasting) merupakan salah satu sub sistem penting dari tiga sub sistem pendukung dalam Effective Government Cash Management System selain manajemen penerimaan dan pengeluaran (management of government receipts and payments) dan manajemen saldo kas Pemerintah (management of government cash balance). Pentingnya perencanaan kas juga disampaikan oleh Williams (2009) dimana pengelolaan dana yang efisien membutuhkan kemampuan perkiraan arus kas harian pada penerapan Treasury Single Account (TSA) idealnya minimal untuk tiga bulan ke depan termasuk kemampuan untuk memantau perubahan aktual perkiraan arus kas secara real time. Williams (2009) menambahkan bahwa sistem perencanaan kas yang paling ideal adalah dengan memanfaatkan arus dua arah informasi baik informasi yang bersifat top down (terkait variasi total penerimaan dan belanja Pemerintah sepanjang waktu) ataupun bottom up (terkait detail rincian informasi pada unit vertikal di bawah Kementerian Keuangan). Namun jenis informasi ini membutuhkan jaringan informasi yang memadai baik yang sifatnya personal maupun berbasis sistem teknologi informasi. Pentingnya teknologi informasi dalam mendukung pelaksanaan perencanaan kas juga disampaikan oleh Mu (2006). Agar perencanaan kas berjalan efektif menurut $\mathrm{Mu}$ (2006) Pemerintah harus memiliki dua unsur pendukung yaitu: (1) adanya suatu model forecasting, dan (2) didukung adanya sistem teknologi informasi.

Dengan fungsi yang sedemikian penting, perencanaan kas Pemerintah ketika tidak dilaksanakan dengan baik tentu membawa dampak yang buruk. Mu (2006) menyebutkan bahwa jika Pemerintah tidak mampu membuat proyeksi cash inflow dan cash outflow secara akurat maka mengakibatkan saldo kas tidak terkontrol dengan baik. Hal tersebut menyebabkan timbulnya biaya yang besar dalam operasional dan Pemerintah tidak mendapatkan pendapatan yang memadai karena tidak dapat melakukan investasi secara akurat.

\subsection{Kebijakan dan Implementasi Perencanaan Kas Pemerintah di Indonesia}

Pada Peraturan Pemerintah (PP) Nomor 39 Tahun 2007 tentang Pengelolaan Uang Negara/Daerah Pasal 32 disebutkan bahwa Menteri Keuangan selaku Bendahara Umum Negara (BUN) pusat bertanggung jawab untuk 
membuat perencanaan kas dan menetapkan saldo kas minimal. Berdasarkan perencanaan arus kas dan saldo kas minimal tersebut, Menteri Keuangan selaku BUN menentukan strategi manajemen kas untuk mengatasi kekurangan kas dan menggunakan kelebihan kas. Dalam rangka penyusunan perencanaan kas pemerintah, kementerian negara/lembaga $(\mathrm{K} / \mathrm{L})$ dan pihakpihak lain yang terkait dengan penerimaan dan pengeluaran APBN wajib menyampaikan proyeksi penerimaan dan pengeluaran secara periodik kepada Menteri Keuangan selaku BUN.

Dalam hal terjadi kekurangan kas, dalam PP Nomor 39 Tahun 2007 Pasal 34 disebutkan bahwa BUN dapat melakukan pinjaman baik dari dalam maupun luar negeri dan/atau menjual atau menerbitkan Surat Utang Negara (SUN), dan/atau menjual surat berharga lainnya sesuai dengan ketentuan peraturan perundangundangan. Sebaliknya, dalam hal terjadi kelebihan kas, BUN setelah berkoordinasi dengan Gubernur Bank Sentral dapat menempatkan uang negara pada rekening di Bank Sentral/Bank Umum yang menghasilkan bunga/jasa giro dengan tingkat bunga yang berlaku. Penempatan uang negara pada Bank Umum dilakukan dengan memastikan bahwa BUN dapat menarik uang tersebut sebagian atau seluruhnya ke Rekening Kas Umum Negara (RKUN) pada saat diperlukan

Implementasi Kebijakan perencanaan kas untuk Tahun Anggaran 2017 diatur dalam PMK Nomor 277/PMK.05/2014 tentang Rencana Penarikan Dana, Rencana Penerimaan Dana dan Perencanaan Kas. PMK Nomor 277/PMK.05/2014 diberlakukan secara efektif mulai bulan Mei 2015 menggantikan peraturan sebelumnya yaitu PMK Nomor 192/PMK.05/2009. Dalam PMK Nomor 277/PMK.05/2014 disebutkan bahwa proses perencanaan kas dimulai dari level satker K/L. Langkah pertama yang dilakukan satker K/L adalah menyusun kalender kegiatan selama satu tahun yang dirinci dalam kegiatan bulanan. Adanya kalender kegiatan selama satu tahun ini juga diharapkan menjadi solusi atas permasalahan tidak meratanya penyerapan anggaran sepanjang tahun dimana sering terjadi penyerapan anggaran hanya menumpuk pada triwulan akhir. Setelah melakukan penyusunan kalender kegiatan secara bulanan, Satker K/L kemudian melakukan rincian kalender kegiatan tersebut dalam kalender kegiatan harian agar perkiraan penarikan dana semakin lebih akurat. Dengan menyusun kalender kegiatan, Satker K/L dapat mengetahui secara detail kapan melakukan pencairan anggaran.
Pencairan anggaran dilakukan satker K/L dengan mengajukan Surat Perintah Membayar (SPM) kepada KPPN. Untuk SPM yang masuk kriteria transaksi besar, satker K/L membuat perencanaan pencairan anggaran yang disebut dengan Rencana Penarikan Dana (RPD) Harian. RPD Harian dibuat oleh satker K/L melalui aplikasi yang disebut Sistem Aplikasi Satker (SAS). RPD Harian memuat informasi nomenklatur Satker, rencana tanggal penarikan dana, jenis belanja dan jumlah nominal penarikan dana.

Penyampaian RPD Harian kepada KPPN diatur dengan adanya norma waktu penyampaian tergantung pada nilai SPM yang akan dicairkan oleh satker K/L. Semakin besar nilai SPM yang diajukan, RPD Harian harus semakin cepat disampaikan kepada KPPN. Berdasarkan laporan dari KPPN nanti Direktorat PKN mempunyai waktu yang cukup untuk mempersiapkan ketersediaan dananya. Dalam periode tunggu setelah satker K/L menyampaikan RPD Harian namun belum dilakukan pengajuan SPM ke KPPN, satker K/L dapat melakukan updating RPD Harian.

Terdapat 9 (Sembilan) tipe Transaksi yang diatur dalam PMK Nomor 277/PMK.05/2014 mulai dari Transaksi A sampai dengan Transaksi I. Jenis transaksi yang dapat dilakukan update data RPD Harian hanya tipe Transaksi A (lebih besar dari Rp1 Triliun) dan Transaksi B (antara Rp500 Miliar sd Rp1 Triliun). Dengan demikian satker K/L dalam menyusun RPD Harian untuk jenis Transaksi C sampai dengan Transaksi I harus disusun seakurat mungkin karena pilihan untuk melakukan update data tidak tersedia. Setiap nilai dari kriteria transaksi besar dibedakan atas jenis transaksinya dan tergantung pada lokasi dan tipe KPPN yang menjadi kantor bayar satker tersebut. Transaksi A, Transaksi B dan Transaksi C hanya terdapat di KPPN tipe A1 yang berlokasi di ibukota propinsi. Transaksi D, Transaksi E dan Transaksi F hanya terdapat di KPPN tipe A1 yang tidak berlokasi di ibukota propinsi. Transaksi G, Transaksi H dan Transaksi I terdapat di KPPN tipe A2.

\subsection{Kualitas Sumber Daya Manusia (SDM)}

Menurut Werther dan Davis (1996) dalam Izzati (2011) pengertian SDM adalah orangorang yang siap, mempunyai keinginan dan mampu untuk berkontribusi dalam tujuan organisasi. Ruky (2003) mendefinisikan Kualitas SDM sebagai tingkat pengetahuan, kemampuan dan kemauan yang dapat ditunjukkan oleh sumber daya manusia. 
Dalam hal perencanaan kas Pemerintah, $\mathrm{Mu}$ (2006) menyebutkan bahwa kemampuan SDM perencanaan kas di negara berkembang masih rendah dikarenakan kurangnya pelatihan dan rendahnya insentif. Octobery (2015) menyebutkan bahwa indikator kualitas SDM antara lain pendidikan, pengalaman, keahlian dan penguasaan teknis, serta motivasi. Quynh et al (2017) menyebutkan bahwa kualitas SDM dipengaruhi oleh empat faktor yaitu dukungan dari atasan, pelatihan dan pengembangan, kapabilitas dalam bekerja dan lingkungan pekerjaan.

\subsection{Kinerja Aplikasi}

Timpe (1992) menyebutkan bahwa kinerja adalah tingkat prestasi yang berhubungan dengan produktivitas. Sedangkan aplikasi sangat erat kaitannya dengan sistem informasi. Sistem informasi menurut Williams dan Sawyer (2007) adalah teknologi dalam bentuk apapun yang membantu manusia dalam membuat, mengubah, menyimpan, mengkomunikasikan dan atau menyebarkan informasi. Kosasi (2014) mengungkapkan bahwa tujuan pengukuran kinerja aplikasi adalah untuk mengetahui sejauh mana aplikasi sudah dapat memberikan manfaat atau masih membutuhkan penyempurnaan.

$\mathrm{Mu}$ (2006) menyebutkan bahwa fungsi sistem informasi adalah mengumpulkan dan memelihara semua data historis terkait pembayaran dan penerimaan dan semua komitmen penerimaan dan pembayaran pemerintah di masa depan serta melakukan pemantauan dan peramalan (forecasting). Lienert (2009) menambahkan bahwa semakin kompleks suatu informasi yang dihasilkan maka semakin besar kebutuhan sistem aplikasi berkualitas tinggi.

Sistem aplikasi berkinerja tinggi menurut Lienert (2009) dibutuhkan untuk memudahkan persiapan dan pemutakhiran proyeksi kas jangka pendek dan pemeliharaan database dan tren arus kas serta mudah dipergunakan (user friendly). Di negara-negara dengan desentralisasi pengelolaan keuangan yang tinggi pada setiap kementerian, adanya proyeksi jangka pendek yang diperbarui secara berkala oleh kementerian dalam sistem teknologi informasi mereka sendiri yang dilaporkan kepada Kementerian Keuangan.

\subsection{Sarana dan Prasarana}

Menurut Kamus Besar Bahasa Indonesia (KBBI), Sarana adalah segala sesuatu yang dapat dipakai sebagai alat dalam mencapai maksud atau tujuan sedangkan prasarana adalah segala sesuatu yang merupakan penunjang utama terselenggaranya suatu proses (usaha, pembangunan, proyek). Muthohar (2012) menyebutkan bahwa satker K/L memerlukan dukungan sarana dan prasarana yang memadai untuk melaksanakan kegiatan perencanaan kas.

\subsection{Sistem Reward and Punishment}

Menurut Nawawi (2005) reward adalah usaha untuk menumbuhkan perasaan diterima di lingkungan kerja yang meliputi aspek kompensasi dan aspek hubungan antara para pekerja yang satu dengan yang lainnya. Nugroho (2006) menyebutkan reward adalah ganjaran, hadiah, penghargaan atau imbalan yang bertujuan agar seseorang menjadi lebih giat dalam usahanya untuk memperbaiki atau meningkatkan kinerja yang telah dicapai.

Terkait punishment, Ivancevich dkk (2006) mendefinisikan sebagai tindakan menyajikan konsekuensi yang tidak menyenangkan atau tidak diinginkan sebagai hasil dari dilakukanya perilaku tertentu. Rivai (2005) membagi punishment dalam tiga bentuk yaitu hukuman ringan, hukuman sedang dan hukuman berat. Dengan demikian punishment merupakan konsekuensi dari perilaku yang negatif yang dilakukan oleh seseorang dan membawa dampak buruk bagi pihak lain.

\subsection{Dispensasi}

Menurut Kamus Besar Bahasa Indonesia (KBBI), dispensasi adalah pengecualian dari aturan karena adanya pertimbangan yang khusus atau adanya pembebasan dari suatu kewajiban atau larangan. Sedangkan Prinz dalam Utrech (1960) mendefinisikan dispensasi sebagai tindakan pemerintahan yang menyebabkan sesuatu peraturan undangundang menjadi tidak berlaku bagi sesuatu hal yang istimewa.

\subsection{Kerangka Penelitian}

Penulis mengembangkan penelitian dengan menetapkan variabel yang berpengaruh terhadap tingkat akurasi RPD Harian yang disusun oleh satker K/L yang terdiri dari Kualitas Sumber Daya Manusia (SDM), Kinerja Aplikasi SAS, Kelengkapan Sarana dan Prasarana, Sistem Reward and Punishment dan Dispensasi. Secara skematis kerangka penelitian dapat dilihat pada gambar berikut ini: 
Gambar 2. : Kerangka Penelitian

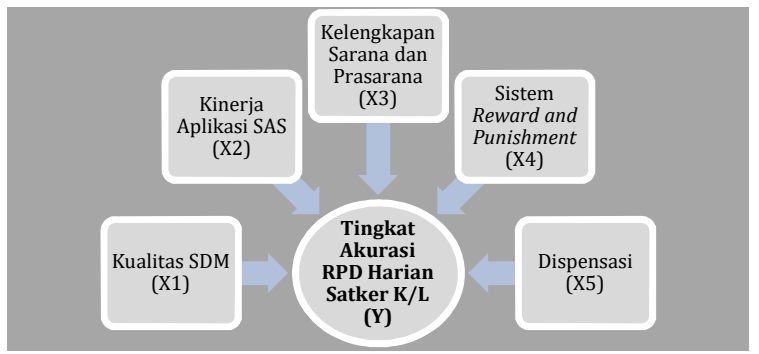

(Sumber: data diolah)

\subsection{Pengembangan Hipotesis}

Berdasarkan kerangka teori, penulis mengembangkan penelitian ini berdasarkan hipotesis sebagai berikut :

H1: Kualitas SDM Satker K/L, Kinerja Aplikasi SAS, Kelengkapan Sarana dan Prasarana Satker K/L, Sistem Reward and Punishment dan Dispensasi secara bersama-sama berpengaruh signifikan terhadap Tingkat Akurasi RPD Harian Satker K/L.

H2: Kualitas SDM Satker K/L mempunyai pengaruh positif dan signifikan terhadap tingkat akurasi RPD Harian Satker K/L.

H3: Kinerja Aplikasi SAS mempunyai pengaruh positif dan signifikan terhadap tingkat akurasi RPD Harian Satker K/L.

H4: Kelengkapan Sarana dan Prasarana Satker $\mathrm{K} / \mathrm{L}$ mempunyai pengaruh positif dan signifikan terhadap tingkat akurasi RPD Harian Satker K/L.

H5: Sistem Reward and Punishment mempunyai pengaruh positif dan signifikan terhadap tingkat akurasi RPD Harian Satker K/L.

H6: Dispensasi atas RPD Harian mempunyai pengaruh negatif dan signifikan terhadap tingkat akurasi RPD Harian Satker K/L.

\section{METODOLOGI PENELITIAN}

\subsection{Jenis Data}

Data yang digunakan penulis dalam penelitian ini terdiri dari dua macam yaitu data primer dan data sekunder. Data primer berasal dari hasil kuisioner terhadap Satker K/L dalam lingkup wilayah pembayaran KPPN Jakarta II yang mengajukan RPD Harian pada Tahun Anggaran 2017. Kuisioner terdiri dari 2 bentuk yaitu paper yang disebarkan secara langsung di KPPN Jakarta II dan secara elektronik melalui tautan yang dikirimkan melalui surel. Data sekunder yang digunakan penulis dalam penelitian ini antara lain data proyeksi belanja, data realisasi belanja dan data tingkat akurasi perencanaan kas. Data primer dan skunder tersebut kemudian ditabulasi dan dilakukan uji regresi logistik.

\subsection{Populasi Penelitian}

Penulis menggunakan seluruh populasi sebagai data dalam penelitian ini yaitu seluruh Satker K/L dalam lingkup wilayah pembayaran KPPN Jakarta II yang mengajukan RPD Harian pada Tahun Anggaran 2017. Berdasarkan data dari aplikasi Online Monitoring SPAN, total Satker K/L yang mengajukan RPD Harian pada Tahun Anggaran 2017 berjumlah 112 Satker.

\subsection{Obyek Penelitian}

Obyek dari penelitian ini adalah seluruh Satker K/L yang mengajukan RPD Harian dalam lingkup wilayah pembayaran KPPN Jakarta II pada tahun anggaran 2017. Alasan pemilihan KPPN Jakarta II sebagai obyek penelitian adalah sebagai berikut :

1. KPPN Jakarta II merupakan KPPN dengan jumlah penyaluran pagu anggaran terbesar di Indonesia yaitu sebesar Rp973 triliun dari total Rp2.070,5 triliun (47\% dari total pagu APBN) dengan sifat dan karakteristik Satker K/L yang heterogen.

2. Tingkat deviasi RPD Harian pada KPPN Jakarta II pada Tahun Anggaran 2016 masih cukup tinggi yaitu sebesar $25,06 \%$.

3. KPPN Jakarta II merupakan salah satu KPPN yang mengelola RPD Harian terbesar di Indonesia dengan total RPD Harian yang diproses sebesar 2.590 buah untuk Tahun Anggaran 2016.

4. Jumlah dispensasi RPD Harian yang dikeluarkan KPPN Jakarta II pada tahun anggaran 2016 masih cukup besar yaitu sebesar 242 buah.

5. KPPN Jakarta II mengelola Satker-satker di bawah BA 999 (BA BUN) yang memiliki pagu sangat besar dan rentan dengan pengajuan dispensasi sehingga dapat menyebabkan tingginya tingkat deviasi RPD Harian tingkat KPPN.

\subsection{Operasionalisasi Variabel}

1. Kualitas SDM

Muthohar (2012) mendefinisikan Kualitas SDM sebagai kompetensi pegawai dalam menyusun proyeksi belanja pada Satker K/L.

Indikator yang digunakan dalam penelitian ini untuk menjelaskan variabel Kualitas SDM berjumlah 8 (delapan) indikator yaitu Tingkat 
Pendidikan Pegawai (KS1), Tingkat Pelatihan Pegawai (KS2), Kemampuan dalam menyusun kalender kegiatan (KS3), Kemampuan Pegawai memahami PMK Nomor 277/PMK.05/2014 (KS4), Kemampuan Pegawai menguasai aplikasi SAS (KS5), Penilaian Pegawai mengenai manfaat melakukan penyusunan RPD Harian (KS6), Pengalaman kerja Pegawai yang menyusun RPD Harian (KS7) serta Adanya insentif bagi Pegawai yang menyusun RPD Harian (KS8).

\section{Kinerja Aplikasi}

Aplikasi yang digunakan Satker K/L dalam menyusun RPD Harian adalah aplikasi Sistem Aplikasi Satker (SAS).

Indikator yang digunakan dalam penelitian ini untuk menjelaskan variabel Kinerja Aplikasi SAS berjumlah 4 (empat) indikator yaitu Kemampuan aplikasi SAS dalam memproses dan menghasilkan data RPD Harian (KA1), Kemampuan aplikasi SAS untuk berinteraksi dengan aplikasi lain (KA2), Kemudahan aplikasi SAS untuk Dioperasikan (KA3) serta Format Tampilan dan Output aplikasi SAS mudah dipahami (KA4).

\section{Kelengkapan Sarana dan Prasarana}

Dalam melakukan penyusunan RPD Harian, Satker K/L membutuhkan dukungan sarana dan prasarana. Sarana utama yang digunakan dalam menyusun RPD Harian adalah komputer/laptop sedangkan prasarana pendukung yang diperlukan antara lain jaringan internet.

Indikator yang digunakan dalam penelitian ini untuk menjelaskan variabel Kelengkapan Sarana dan Prasarana Satker K/L berjumlah 4 (empat) indikator yaitu Satker K/L memiliki Sarana yang lengkap berupa komputer/laptop dan software aplikasi (KSP1), Kelengkapan Sarana yang dimiliki oleh Satker K/L mendukung pencapaian RPD Harian yang akurat (KSP2), Satker K/L memiliki Prasarana yang lengkap berupa jaringan internet, e-mail, dan smartphone (KSP3) serta Kelengkapan Prasarana yang dimiliki oleh Satker K/L mendukung pencapaian RPD Harian yang akurat (KSP4).

\section{Sistem Reward and Punishment}

Williams (2004) menyebutkan bahwa pemberian insentif diperlukan untuk pengelolaan dana yang efisien pada semua tingkat pemerintahan untuk meminimalkan tingkat saldo kas dan menciptakan kepastian yang lebih besar terkait waktu pembayaran dan atau penerimaan. Insentif semacam itu dapat dalam bentuk hukuman atas kepemilikan saldo kas yang berlebihan. Lienert (2009) menyebutkan bahwa penalti/hukuman perlu diberikan agar satuan kerja (agencies) menyampaikan proyeksi yang akurat dan insentif perlu diberikan kepada budget institution yang mampu memberikan proyeksi kas yang realistis.

Indikator yang digunakan dalam penelitian ini untuk menjelaskan variabel Sistem Reward and Punishment berjumlah 4 (empat) indikator yaitu Urgensi adanya reward atas pelaksanaan kebijakan RPD Harian (RP1), Ketepatan atas jenis reward yang diberikan (RP2), Urgensi adanya punishment atas pelaksanaan kebijakan RPD Harian Satker K/L (RP3) serta Ketepatan atas jenis punishment yang diberikan (RP4).

\section{Dispensasi}

Dispensasi merupakan kebijakan baru yang mulai diterapkan dalam implementasi PMK Nomor 277/PMK.05/2014 tentang Rencana Penarikan Dana, Rencana Penerimaan Dana dan Perencanaan Kas mulai tahun 2015. Dispensasi merupakan permohonan yang diajukan Satker K/L kepada Kepala KPPN agar Satker K/L tidak perlu mengajukan RPD Harian untuk pencairan SPM yang masuk kriteria transaksi besar. Setiap dispensasi yang dikeluarkan kepada Satker K/L dikenai deviasi sebesar 100\% dikarenakan Satker K/L dianggap tidak menyampaikan RPD Harian.

Indikator yang digunakan dalam penelitian ini untuk menjelaskan variabel Dispensasi berjumlah 3 (tiga) indikator yaitu Akibat adanya kebijakan dispensasi dalam pengajuan RPD Harian ke KPPN terhadap tingkat akurasi perencanaan kas Pemerintah Pusat (D1), Ketepatan jenis SPM yang dapat diberikan fasilitas dispensasi (D2) serta Perlu tidaknya penggunaan Dispensasi oleh Satker K/L dalam pengajuan RPD Harian ke KPPN (D3).

\section{Tingkat Akurasi RPD Harian Satker K/L}

Variabel terikat dalam penelitian ini adalah Tingkat Akurasi RPD Harian Satker K/L. Dalam penelitian ini indikator yang digunakan untuk menjelaskan variabel Tingkat Akurasi RPD Harian Satker K/L adalah apakah Satker dapat/tidak dapat menyusun RPD Harian dengan akurat. Direktorat Jenderal Perbendaharaan memberikan batas deviasi RPD Harian sebesar 15\% untuk RPD Harian yang masuk kriteria akurat dan dokumen SPM yang diajukan oleh Satker K/L dapat diproses oleh KPPN.

\subsection{Uji Reliabilitas dan Uji Validitas Kuisioner}

Ghozali (2016) menyebutkan bahwa setelah kuisioner selesai disusun, sebelum disebarkan kepada responden kuisioner harus dilakukan uji reliabilitas dan uji validitas terlebih dahulu. Pada 
penelitian di bidang ilmu sosial pada umumnya variabel-variabel penelitiannya dirumuskan sebagai variabel latent atau unobserved melalui indikator-indikator yang diamati. Kuisioner biasanya menggunakan skala likerts yaitu skala yang berisi lima preferensi yaitu 1 (Sangat Tidak Setuju) sampai dengan 5 (Sangat Setuju).

Uji validitas untuk mengukur sah atau valid tidaknya suatu kuesioner yang dilakukan. Suatu kuesioner dikatakan valid jika pertanyaan pada kuesioner mampu mengungkapkan sesuatu yang diukur oleh kuesioner tersebut. Suatu indikator pada kuesioner dinyatakan valid apabila nilai Total Pearson Correlation masing-masing indicator mempunyai koefisien korelasi lebih besar dari nilai $r$ tabel.

Uji Reliabilitas merupakan alat untuk mengukur suatu kuisioner yang merupakan indikator dari suatu variabel. Suatu kuisioner dikatakan reliabel atau handal jika jawaban responden terhadap pernyataan adalah konsisten dari waktu ke waktu. Hair et al (2010) dan Basri (2012) menyebutkan bahwa suatu variabel dikatakan memiliki reliabilitas yang moderat/cukup jika memberikan nilai Croncbach Alpha > nilai 0,5 - 0,7.

\subsection{Teknik Analisis Data}

Penelitian ini menggunakan jenis Analisis Multivariat berupa Regresi Logistik. Ghozali (2016) menyebutkan bahwa Regresi Logistik digunakan dikarenakan adanya asumsi multivariate normal distribution tidak dapat dipenuhi karena variabel bebas merupakan campuran antara variabel kontinyu (metrik) dan kategorial (non-metrik). Santoso (2016) menyebutkan bahwa pada Regresi Logistik, variabel terikat (dependen) adalah data nominal/kategorial khususnya data binary. Model Logit merupakan model regresi non linear yang menghasilkan sebuah persamaan dimana variabel dependen bersifat kategorial. Kategori paling dasar dari model tersebut menghasilkan binary value misalnya angka 0 dan 1 . Angka yang dihasilkan mewakili suatu kategori tertentu yang dihasilkan dari perhitungan probabilitas terjadinya kategori tersebut.

\subsection{Model Penelitian dan Evaluasi Model}

Berdasarkan berbagai literatur tersebut, penulis menggunakan Regresi Logistik dalam melakukan analisis penelitian ini. Penulis menggunakan Binary Logistic Regression dengan model persamaan yang dikembangkan dalam penelitian adalah sebagai berikut:

$$
\begin{aligned}
& \text { Logit Model }=\operatorname{Ln} \frac{P}{1-P}=\alpha+\beta_{1} K S_{\mathrm{i}}+ \\
& \beta_{2} K A_{\mathrm{i}}+\beta_{3} K S P_{\mathrm{i}}+\beta_{4} R P_{\mathrm{i}}+\beta_{5} D_{\mathrm{i}}
\end{aligned}
$$

dimana :

Ln $\frac{P}{1-P}$ : $\quad$ Mengacu pada probabilitas untuk RPD Harian yang dihasilkan Harian yang dihasilkan tidak akurat

KS : Kualitas SDM Satker K/L

KA : Kinerja Aplikasi SAS

KSP : Kelengkapan Sarana dan Prasarana Satker K/L,

RP : Reward and Punishment, dan

D : Dispensasi

Model tersebut mengacu pada penelitian Munir (2016) yang meneliti tentang faktor-faktor yang memengaruhi kepuasan pelanggan terhadap pelayanan e-banking di Bangladesh menggunakan metode kuisioner dengan teknik random sampling dari tujuh kota berbeda di Bangladesh. Jumlah sampel yang diambil sebesar 350 dengan kuisioner menggunakan skala likerts 1 sampai dengan 5. Munir (2016) pada tahap awal juga melakukan uji validitas dan uji reliabilitas kuisioner. Model persamaan yang digunakan Munir (2016) adalah:

Logit $(\mathrm{Y})=\alpha+\beta 1 \mathrm{X} 1+\beta 2 \mathrm{X} 2+\beta 3 \mathrm{X} 3$, dimana:

$\mathrm{Y}:$ : Kepuasan Pelanggan (CSAT)

X1 : Kualitas Informasi (IQ)

X2 : Kualitas Pelayanan (SERQ)

X3 : Kualitas Sistem Informasi (SYSQ)

Hasil dari Regresi menunjukkan ada hubungan positif antara variabel Kepuasan Pelanggan dengan variabel Kualitas Pelayanan.

Santoso (2016) menyebutkan bahwa evaluasi model yang dilakukan dalam regresi logistik antara lain:

\section{Omnibus Tests of Model Coefficients}

Nilai signifikansi Omnibus Tests dengan jumlah variabel independen sebanyak $\mathrm{x}$ harus berada di bawah 0,05 (jika menggunakan taraf signifikansi 5\%). Hal tersebut menunjukkan bahwa terdapat pengaruh yang signifikan dari $\mathrm{x}$ variabel independen secara simultan memengaruhi variabel dependen. Hipotesis yang dikembangkan adalah:

$\mathrm{H}_{0}$ : Penambahan variabel independen tidak dapat memberikan pengaruh nyata terhadap model.

$\mathrm{H}_{1}$ : Penambahan variabel independen dapat memberikan pengaruh nyata terhadap model. 
Nilai Omnibus Test pada uji ini adalah Jika probabilitas > 0,05 maka $\mathrm{H}_{0}$ gagal untuk ditolak sedangkan Jika probabilitas $\leq 0,05$ maka $\mathrm{H}_{0}$ ditolak.

\section{Nagelkerke's R Square}

Nagelkerke's $R$ Square merupakan modifikasi dari koefisien Cox \& Snell's $R$ Square untuk memastikan bahwa nilainya bervariasi dari 0 sampai 1 . Hal ini dilakukan dengan cara membagi nilai Cox \& Snell $R$ Square dengan nilai maksimumnya. Nagelkerke's $R$ Square juga dikenal dengan Koefisien Determinasi $\left(R^{2}\right)$ yang digunakan untuk mengetahui seberapa besar variabilitas variabel dependen.

\section{Hosmer and Lemeshow's Goodness of Fit Test}

Hosmer and Lemeshow's Goodness of Fit Test menguji hipotesis nol bahwa data empiris cocok atau sesuai dengan model (tidak ada perbedaan antara model dengan data sehingga model dapat dikatakan fit). Hipotesis yang dikembangkan adalah:

$\mathrm{H}_{0}$ : Tidak ada perbedaan nyata antara klasifikasi yang diprediksi dan klasifikasi yang diamati atau model fit dengan data.

$\mathrm{H}_{1}$ : Ada perbedaan yang nyata antara klasifikasi yang diprediksi dan klasifikasi yang diamati atau model tidak fit dengan data.

Nilai goodness of fit test yang diukur dengan nilai chi-square pada uji ini adalah Jika probabilitas > 0,05 maka $\mathrm{H}_{0}$ gagal untuk ditolak sedangkan jika probabilitas $\leq 0,05$ maka $\mathrm{H}_{0}$ ditolak.

\section{Uji Simultan dan Uji Parsial}

Untuk mengetahui pengaruh variabel bebas terhadap variabel terikat secara bersama-sama di dalam model dapat menggunakan uji G atau Likelihood Ratio Test. Pada Uji G ini statistik uji yang digunakan adalah:

$$
\mathrm{G}^{2}=-2 \ln \left|\frac{L_{0}}{L_{1}}\right|
$$

Statistik G mengikuti distribusi chi-square dengan derajat bebas $p$ sehingga hipotesis ditolak jika nilai probabilitas $\geq$ chi-square atau pvalue $\leq \alpha$ yang berarti variabel bebas $X$ secara bersama-sama memengaruhi variabel terikat Y. Hipotesisnya dapat dituliskan sebagai berikut: $\mathrm{H}_{0}: \beta 1=\beta 2=\ldots .=\beta \mathrm{p}=0$

(tidak ada pengaruh variabel bebas secara simultan terhadap variabel terikat)

$\mathrm{H}_{1}$ : Minimal ada satu $\beta \mathrm{i} \neq 0 ; \mathrm{i}=1,2, \ldots, \mathrm{p}$ (ada pengaruh variabel bebas secara simultan terhadap variabel terikat)
Uji parsial digunakan untuk mencari model yang cocok dan keterkaitan kuat antara model dengan datanya atau untuk mengetahui pengaruh koefisien $\beta$ dibandingkan dengan standar error-nya. Uji parsial menggunakan uji wald. Statistik uji yang digunakan adalah :

$$
\mathrm{W}=\left(\frac{\beta_{i}}{S E\left(\beta_{i}\right)}\right)^{2}
$$

Hipotesis yang digunakan adalah :

$\mathrm{H}_{0}: \beta_{\mathrm{i}}=0$ (tidak ada pengaruh variabel bebas terhadap variabel terikat)

$\mathrm{H}_{1}: \beta_{\mathrm{i}} \neq 0$ (ada pengaruh variabel bebas terhadap variabel terikat)

Hipotesis nol ditolak jika $p$-value $\leq \alpha$ yang berarti secara parsial variabel bebas $\mathrm{X}$ memengaruhi variabel terikat Y.

\section{Odds Ratio}

Odds ratio (rasio peluang) merupakan ukuran risiko atau kecenderungan untuk mengalami kejadian sukses antara satu kategori dengan kategori lainnya. Regresi logistik binary menghasilkan odds ratio terkait dengan nilai setiap prediktor. Rasio peluang bagi prediktor diartikan sebagai jumlah relatif dimana peluang hasil meningkat (dimana rasio peluang $>1$ ) atau turun (dimana rasio peluang $<1$ ) ketika variabel bebas mengalami peningkatan sebesar 1 unit.

\section{HASIL PENELITIAN}

\subsection{Hasil Uji Validitas dan Reliabilitas}

Penyebaran kuisioner untuk melakukan uji validitas dan uji reliabilitas kuisioner dilaksanakan pada hari Rabu tanggal 6 Desember 2017 di KPPN Jakarta II. Uji validitas dan reliabilitas kuisioner ini dilakukan secara langsung terhadap 30 responden Satker K/L. Setelah dilakukan tabulasi data dan dilakukan uji validitas dan uji reabilitas data dengan menggunakan alat pengolah data, seluruh indikator variabel pada kuisioner dinyatakan valid dan reliabel.

\subsection{Responden Penelitian}

Setelah seluruh kuisioner dinyatakan valid dan reliabel, penulis melakukan penyebaran kuisioner kepada seluruh responden yang menjadi populasi penelitian yang berjumlah total 112 Satker K/L dimana setiap Satker K/L mengisi satu kuisioner. Dari 112 responden tersebut, 77 responden mengisi kuisioner secara langsung di KPPN Jakarta II dan 35 responden mengisi kuisioner melalui tautan yang dikirim penulis melalui surel. 
Rincian responden dalam penelitian ini adalah Kementerian Energi Sumber Daya Mineral (ESDM) sebanyak 10 Satker, Kementerian Keuangan sebanyak 37 Satker, Kementerian Pemberdayaan Perempuan dan Perlindungan Anak sebanyak 6 Satker, Kementerian BUMN sebanyak 1 Satker, Badan Pusat Statistik sebanyak 9 Satker, Kementerian Pertahanan sebanyak 11 Satker, Lembaga Administrasi Negara sebanyak 2 Satker, Kementerian Perencanaan Pembangunan Nasional/BAPPENAS sebanyak 1 Satker, Kementerian Koordinator Bidang Perekonomian sebanyak 2 Satker, Perpustakaan Nasional sebanyak 1 Satker dan Bendahara Umum Negara sebanyak 32 Satker.

\subsection{Analisis Hasil Regresi Logistik}

\section{Omnibus Test of Model Coefficients}

Hasil dari nilai $\mathrm{X}^{2}$ sebesar $34.125>$ nilai $\mathrm{X}^{2}$ tabel pada DF 5 yaitu 11.071. Jika mengacu pada nilai signifikansinya, maka nilai $0.000<0.05$ sehingga $\mathrm{H}_{0}$ ditolak. Hasil tersebut menunjukkan bahwa penambahan variabel independen dapat memberikan pengaruh nyata terhadap model atau dengan kata lain model dinyatakan Fit.

\section{Nagelkerke R Square}

Nilai Nagelkerke R Square yang dihasilkan adalah sebesar 0,554. Hal tersebut menunjukkan bahwa kemampuan variabel bebas dalam menjelaskan variabel terikat adalah sebesar $55,4 \%$ dan terdapat $44,6 \%$ faktor-faktor lainnya di luar model yang menjelaskan variabel terikat.

\section{Hosmer and Lemeshow Test}

Nilai Chi Square tabel untuk DF 8 pada taraf signifikansi 0.05 adalah sebesar 15.507. Karena nilai Chi Square Hosmer and Lemeshow hitung sebesar 10.284, maka nilai Chi Square Hosmer and Lemeshow hitung < nilai Chi Square tabel. Jika mengacu pada nilai signifikansinya maka menghasilkan $0.212>0.05$ sehingga $\mathrm{H}_{0}$ gagal untuk ditolak. Hasil tersebut menunjukkan bahwa model dapat diterima dan pengujian hipotesis dapat dilakukan dikarenakan tidak ada perbedaan signifikan antara model dengan nilai observasinya.

\section{Tabel Klasifikasi}

Nilai overall percentage penelitian ini sebesar 0.955 yang berarti ketepatan model yang digunakan dalam penelitian ini adalah sebesar 95.5\%.

\section{Hasil Uji Simultan}

Untuk menguji signifikansi pada regresi logistik menggunakan pengujian Maximum likelihood. Uji simultan ditunjukkan dengan nilai $\mathrm{G}^{2}$ dimana nilainya $=-2 \ln \left(\mathrm{L}_{0}\right)-\left[-2 \ln \left(\mathrm{L}_{1}\right)\right]=$ $71.936-37.811=34.125$. Untuk melihat signifikansinya, hasil dari nilai $\mathrm{G}^{2}$ dibandingkan dengan nilai Chi Square $\left(\mathrm{X}^{2}\right)$ dengan derajat bebas sebesar banyaknya variabel independen $(\mathrm{df}=5)$ yaitu sebesar 11.070. Karena nilai $\mathrm{G}^{2}$ yaitu sebesar $34.125>$ nilai chi square yaitu sebesar 11.070 maka $\mathrm{H}_{0}$ ditolak. Hasil tersebut berarti bahwa variabel Kualitas SDM Satker K/L, Kinerja Aplikasi SAS, Kelengkapan Sarana dan Prasarana Satker K/L, Sistem Reward and Punishment dan Dispensasi secara bersama-sama berpengaruh signifikan terhadap variabel Tingkat Akurasi RPD Harian.

\section{Hasil Uji Parsial}

Uji Parsial dilakukan dengan menggunakan hasil uji wald. Hasil dari uji wald ditunjukkan dalam tabel berikut ini:

Tabel 4.1 Tabel Hasil Uji Wald

\begin{tabular}{|c|c|c|c|c|c|c|c|c|}
\hline \multicolumn{9}{|c|}{ Variables in the Equation } \\
\hline & \multirow{2}{*}{ B } & \multirow{2}{*}{ S.E. } & \multirow{2}{*}{ Wald } & \multirow{2}{*}{ df } & \multirow{2}{*}{ Sig. } & \multirow{2}{*}{$\operatorname{Exp}(B)$} & \multicolumn{2}{|c|}{$\begin{array}{l}\text { 95\% C.I.for } \\
\text { EXP(B) }\end{array}$} \\
\hline & & & & & & & Lower & Upper \\
\hline KS & .298 & .148 & 4.040 & 1 & .044 & 1.347 & 1.007 & 1.802 \\
\hline KA & .652 & .299 & 4.765 & 1 & .029 & 1.920 & 1.069 & 3.447 \\
\hline KSP & .015 & .300 & .003 & 1 & .960 & 1.015 & .564 & 1.826 \\
\hline $\mathrm{RP}$ & .182 & .225 & .657 & 1 & .418 & 1.200 & .772 & 1.865 \\
\hline $\mathrm{D}$ & .246 & .367 & .450 & 1 & .502 & 1.279 & .623 & 2.625 \\
\hline Const & -21.708 & 6.891 & 9.925 & 1 & .002 & .000 & & \\
\hline
\end{tabular}

Sumber: data diolah

Berdasarkan nilai-nilai pada koefisien B pada tabel di atas, maka model persamaan yang dapat dibentuk adalah sebagai berikut:

$$
\begin{aligned}
& \operatorname{Ln}\left[\frac{P}{1-P}\right]=-21.708+0.298 K S^{* *}+ \\
& 0.652 K A^{* *}+0.015 K S P+0.182 R P+ \\
& 0.246 D
\end{aligned}
$$

Dari tabel di atas menunjukkan bahwa terdapat dua variabel independen memiliki nilai $\mathrm{P}$ value uji wald (Sig) < $\alpha$, yang berarti kedua variabel independen tersebut masing-masing mempunyai pengaruh parsial yang positif dan signifikan terhadap variabel dependen di dalam model. Kedua variabel independen tersebut 
adalah Kualitas SDM Satker K/L (KS) dan Kinerja Aplikasi SAS(KA). Besarnya pengaruh dari variabel independen ditunjukkan dengan nilai EXP (B) atau disebut juga dengan Odds Ratio (OR) dengan rincian sebagai berikut:

a) Pengaruh Kualitas SDM Satker K/L terhadap Tingkat Akurasi RPD Harian

Kualitas SDM mempunyai nilai Sig Wald $0,044<0,05(\alpha=5 \%)$ sehingga $\mathrm{H}_{0}$ ditolak atau berarti Kualitas SDM memberikan pengaruh signifikan terhadap kondisi RPD Harian yang akurat. Variabel Kualitas SDM dengan nilai Odds Ratio sebesar 1,347 berarti jika Kualitas SDM lebih tinggi maka memiliki kecenderungan RPD Harian yang akurat sebesar 1,347 kali lipat dibandingkan Kualitas SDM rendah. Nilai B merupakan Logaritma Natural dari Exp (B) sebesar 1,347 adalah 0,298. Oleh karena nilai B bernilai positif maka variabel Kualitas SDM mempunyai hubungan positif dengan kondisi RPD Harian yang akurat.

Hasil penelitian ini mendukung penelitian sebelumnya antara lain $\mathrm{Mu}$ (2006) dan Lienert (2009) yang menekankan bahwa Kualitas SDM pengelola kas Pemerintah memegang peranan yang sangat penting dalam melaksanakan kebijakan manajemen kas Pemerintah. Hasil penelitian ini juga sesuai dengan penelitian Sembiring (2013) yang menyimpulkan bahwa Kualitas SDM berpengaruh signifikan positif terhadap keandalan dan ketepatan waktu pelaporan keuangan pemerintah daerah Kota Padang.

b) Pengaruh Kinerja Aplikasi SAS terhadap Tingkat Akurasi RPD Harian

Kinerja Aplikasi SAS mempunyai nilai Sig Wald $0,029<0,05(\alpha=5 \%)$ sehingga $\mathrm{H}_{0}$ ditolak atau berarti Kinerja Aplikasi SAS memberikan pengaruh signifikan terhadap kondisi RPD Harian yang akurat. Variabel Kinerja Aplikasi SAS dengan nilai Odds Ratio sebesar 1.920 berarti jika Kinerja Aplikasi SAS tinggi maka akan memiliki kecenderungan RPD Harian yang akurat sebesar 1.920 kali lipat dibandingkan Kinerja Aplikasi SAS rendah. Nilai B merupakan Logaritma Natural dari Exp (B) sebesar 1.920 adalah 0,652 . Oleh karena nilai B bernilai positif, maka variabel Kinerja Aplikasi SAS mempunyai hubungan positif dengan kondisi RPD Harian yang akurat.

Hasil penelitian ini mendukung penelitian sebelumnya antara lain Lienert (2009) yang menyimpulkan bahwa semakin kompleks suatu informasi yang dihasilkan dalam kegiatan manajemen kas modern maka semakin besar kebutuhan sistem informasi dan aplikasi berkualitas tinggi. Penelitian Indriasari dan Nahartyo (2008) juga menemukan bahwa pemanfaatan teknologi informasi dan pengendalian intern akuntansi berpengaruh positif dan signifikan terhadap keandalan pelaporan keuangan pemerintah daerah. Hasil penelitian ini juga sesuai dengan penelitian Muthohar (2012) yang menyimpulkan bahwa kualitas Aplikasi Forecasting Satker (AFS) meningkatkan efektivitas proyeksi belanja Satker K/L.

c) Pengaruh Kelengkapan Sarana dan Prasarana Satker K/L terhadap Tingkat Akurasi RPD Harian

Kelengkapan Sarana dan Prasarana mempunyai nilai Sig Wald 0,960 > 0,05 ( $\alpha=5 \%)$ sehingga $\mathrm{H}_{0}$ gagal untuk ditolak atau berarti tidak ada pengaruh secara statistik variabel Kelengkapan Sarana dan Prasarana terhadap kondisi RPD Harian yang akurat. Namun, ketika dilakukan uji wald per indikator dari variabel Kelengkapan Sarana dan Prasarana terdapat satu indikator yang terdapat satu indikator yang berpengaruh signifikan terhadap kondisi RPD Harian yang akurat yaitu indikator pengaruh Kelengkapan Prasarana yang dimiliki oleh Satker K/L atas pencapaian RPD Harian yang akurat (KSP4). Hal ini menunjukkan secara individual Prasarana yang dimiliki Satker K/L seperti jaringan internet memiliki peran yang penting dalam mendukung pencapaian RPD Harian yang akurat.

Hasil penelitian yang menunjukkan tidak berpengaruhnya secara statistik variabel Kelengkapan Sarana dan Prasarana Satker K/L terhadap kondisi RPD Harian yang akurat ini mendukung hasil penelitian sebelumnya antara lain penelitian Muthohar (2012) yang menyimpulkan bahwa kelengkapan sarana dan prasana yang dimiliki satker tidak memiliki pengaruh signifikan terhadap efektivitas proyeksi belanja satker.

Tidak berpengaruhnya secara statistik variabel Kelengkapan Sarana dan Prasarana antara lain dikarenakan obyek penelitian yaitu Satker K/L lingkup wilayah pembayaran KPPN Jakarta II merupakan Satker K/L yang berlokasi di ibu kota Jakarta. Dengan demikian hampir dapat dipastikan seluruh Satker Kementerian/ Lembaga memiliki sarana dan prasarana yang lengkap sehingga dimungkinkan variasi data yang dihasilkan kecil. Selain hal tersebut, DKI Jakarta tentu saja juga memiliki fasilitas transportasi yang memadai sehingga misalnya terjadi gangguan dalam pengiriman data RPD 
Harian melalui jaringan internet maka Saker K/L dengan mudah mengirimkan secara langsung ke KPPN Jakarta II. Hal tersebut tentu berbeda kondisinya untuk Satker K/L yang berdomisili di luar jawa yang memiliki fasilitas serta sarana dan prasarana yang terbatas dimana variabel Kelengkapan Sarana dan Prasarana dimungkinkan memiliki pengaruh signifikan. Namun tentu saja hal tersebut memerlukan penelitian tersendiri lebih lanjut.

d) Pengaruh Sistem Reward and Punishment terhadap Tingkat Akurasi RPD Harian

Sistem Reward and Punishment mempunyai nilai Sig Wald 0,418 $>0,05(\alpha=5 \%)$ sehingga $\mathrm{H}_{0}$ gagal untuk ditolak atau berarti tidak ada pengaruh secara statistik variabel Sistem Reward and Punishment terhadap kondisi RPD Harian yang akurat. Namun, ketika dilakukan uji wald per indikator dari variabel Sistem Reward and Punishment, terdapat satu indikator yang berpengaruh signifikan terhadap kondisi RPD Harian yang akurat yaitu indikator Ketepatan atas jenis reward yang diberikan (RP2). Hal ini menunjukkan bahwa secara individual ketepatan jenis reward yang diberikan Direktorat PKN dapat memacu Satker K/L untuk menghasilkan penyusunan RPD Harian yang akurat. Dengan demikian diharapkan Direktorat PKN mampu merumuskan jenis reward yang tepat agar Satker $\mathrm{K} / \mathrm{L}$ semakin termotivasi dalam menyusun RPD Harian yang akurat.

Hasil penelitian ini menunjukkan tidak berpengaruhnya secara statistik Sistem Reward and Punishment terhadap kondisi RPD Harian yang akurat ini berbeda dengan hasil penelitian Muthohar (2012) yang menyimpulkan bahwa Reward and Punishment memiliki pengaruh positif dan signifikan terhadap efektivitas proyeksi belanja satker. Hasil penelitian ini juga berbeda dengan kesimpulan Lienert (2009) yang menyebutkan bahwa pinalti/hukuman perlu diberikan agar satuan kerja (agencies) menyampaikan proyeksi yang akurat dan insentif perlu diberikan pada budget institution yang mampu memberikan proyeksi kas yang realistis.

Tidak berpengaruhnya secara statistik variabel Sistem Reward and Punishment antara lain disebabkan belum berjalannya mekanisme Reward and Punishment sesuai dengan yang diatur dalam PMK Nomor 277/PMK.05/2014. Terkait dengan Reward, dalam PMK Nomor 277/PMK.05/2014 disebutkan bahwa KPPN memberikan layanan prioritas tanpa antrian selama satu bulan kepada Satker K/L sebagai penghargaan atas penyampaian RPD Harian yang tepat waktu dan akurat dimana Satker tersebut telah menyampaikan RPD Harian dengan tingkat deviasi maksimal 5\% (lima persen) selama satu bulan.

Namun dalam pelaksanaannya, bentuk Reward ini masih belum diterapkan secara penuh. KPPN Jakarta II sebenarnya memberikan reward berupa layanan prioritas bebas antrian kepada tiga Satker K/L terbaik, namun kriteria yang digunakan bukan hanya capaian tingkat akurasi RPD Harian tetapi juga tingkat penyerapan dan rekonsiliasi LPJ Bendahara. Pemberian reward ini juga tidak dilakukan secara konsisten sepanjang tahun, namun dilakukan pada triwulan keempat yaitu pada bulan September atau Oktober. Hal ini menunjukkan kegiatan evaluasi bulanan atas capaian akurasi RPD Harian Satker K/L belum berjalan dengan konsisten sepanjang tahun dan belum ada penerapan reward yang diberikan secara khusus terkait capaian tingkat akurasi RPD Harian Satker K/L.

Hasil kuisioner menunjukan bahwa mayoritas Satker K/L memiliki harapan agar reward sebagaimana yang diatur dalam PMK Nomor 277/PMK.05/2014 yaitu pemberian layanan prioritas bebas antrian bagi Satker Kementerian Lembaga yang memiliki tingkat deviasi maksimal $5 \%$ setiap bulan agar diterapkan secara konsisten sepanjang tahun oleh KPPN. Penerapan kebijakan tersebut diharapkan dapat memberi motivasi kepada Satker K/L dalam meningkatkan akurasi RPD Harian Satker K/L.

Terkait dengan Punishment, dalam PMK Nomor 277/PMK.05/2014 disebutkan bahwa KPPN juga dapat melakukan penolakan SPM yang diajukan oleh Satker yang tidak menyampaikan RPD Harian atau terlambat menyampaikan RPD Harian. Namun kebijakan ini belum sepenuhnya berjalan dikarenakan Satker yang tidak menyampaikan RPD Harian tidak serta merta mendapatkan penolakan SPM dari KPPN. Pihak KPPN harus mempertimbangkan berbagai aspek lainnya dalam mengambil keputusan antara lain terkait tingkat urgensi pencairan SPM dan risiko yang bersifat eksternal dalam memutuskan menerima atau menolak pencairan SPM tanpa RPD Harian. Dengan demikian Satker K/L masih dapat mencairkan SPM tanpa RPD Harian melalui mekanisme pemberian dispensasi oleh Kepala KPPN sesuai yang diatur dalam PMK Nomor 277/PMK.05/2014.

e) Pengaruh Dispensasi terhadap Tingkat Akurasi RPD Harian

Dispensasi mempunyai nilai Sig Wald 0,502 $>0,05(\alpha=5 \%)$ sehingga $\mathrm{H}_{0}$ gagal untuk ditolak 
atau berarti tidak ada pengaruh secara statistik variabel Dispensasi terhadap kondisi RPD Harian yang akurat. Begitu juga ketika dilakukan uji wald per indikator dari variabel Dispensasi, juga tidak terdapat indikator yang berpengaruh signifikan terhadap Tingkat Akurasi RPD Harian.

Hasil penelitian ini berbeda dengan penelitian sebelumnya yang menyebutkan bahwa Dispensasi dalam penyusunan perencanaan kas dapat menimbulkan efek negatif dalam manajemen kas Pemerintah antara lain Mu (2006) menyebutkan bahwa bahwa jika Pemerintah tidak mampu membuat proyeksi cash inflow dan cash outflow secara akurat maka mengakibatkan saldo kas tidak terkontrol dengan baik.

Berdasarkan PMK Nomor 277/PMK.05/2014, Kepala KPPN dapat memberikan dispensasi pencairan SPM tanpa RPD Harian yang masuk dalam kriteria transaksi mendesak lainnya yang disetujui Kepala KPPN dan dalam implementasinya setelah mendapat berbagai masukan dari KPPN, SPM dengan dispensasi tersebut dihitung sebagai SPM yang akurat sehingga mempunyai deviasi $0 \%$.

Sebagai langkah antisipasi, Direktur PKN dalam surat Nomor S-4166/PB.3/2016 tanggal 19 Mei 2016 tentang Pemberian Dispensasi Penyampaian RPD Harian, telah memberikan panduan dalam pemberian dispensasi yaitu bahwa Kepala KPPN dalam memberikan dispensasi harus bersifat selektif dan edukatif. Secara selektif berarti bahwa Kepala KPPN agar meneliti secara seksama bahwa kegiatan yang dibiayai oleh SPM dimaksud benar-benar bersifat penting dan mendesak. Secara edukatif berarti bahwa KPPN agar tetap memberikan pembinaan kepada Satker K/L agar pengajuan SPM selanjutnya dapat didahului oleh penyampaian RPD Harian. Selain itu Direktur PKN juga mewajibkan kepada KPPN untuk melakukan pengisian alasan pemberian dispensasi secara jelas dan spesifik pada aplikasi konversi agar dapat dilakukan evaluasi oleh Direktorat PKN. Dengan demikian diharapkan seiring berjalannya waktu semua Satker K/L dapat menjalankan kebijakan penyusunan RPD Harian dengan lebih baik.

Salah satu langkah yang dapat dilakukan Direktorat PKN agar masih tingginya angka dispensasi RPD Harian tidak memengaruhi pengelolaan likuiditas kas Pemerintah adalah dengan memberikan jangka waktu pencairan atas SPM tanpa RPD Harian baik dalam hitungan hari atau minggu sesuai dengan besar kecilnya jumlah SPM yang diajukan Satker K/L. Dengan demikian setiap pengajuan SPM tanpa RPD Harian tidak serta merta pada hari itu juga dapat dicairkan. Hal tersebut diharapkan dapat mendorong Satker K/L untuk menyusun RPD Harian atas SPM yang masuk kriteria transaksi besar dan mengurangi pengajuan dispensasi kepada Kepala KPPN.

\section{KESIMPULAN DAN SARAN}

\subsection{Kesimpulan}

1. Kualitas SDM, Kinerja Aplikasi SAS, Kelengkapan Sarana dan Prasarana, Sistem Reward and Punishment dan Dispensasi secara bersama-sama berpengaruh signifikan terhadap Tingkat Akurasi RPD Harian.

2. Secara parsial, hubungan antar variabel adalah sebagai berikut :

a) Kualitas SDM Satker K/L dan Kinerja Aplikasi SAS memberikan pengaruh positif dan signifikan terhadap terjadinya kondisi RPD Harian yang akurat.

b) Kelengkapan Sarana dan Prasarana Satker K/L, Sistem Reward and Punishment dan Dispensasi tidak memberikan pengaruh secara statistik terhadap terjadinya kondisi RPD Harian yang akurat. Namun, secara individual terdapat indikator yang berpengaruh positif dan signifikan terhadap terjadinya kondisi RPD Harian yang akurat yaitu Prasarana yang dimiliki Satker K/L (indikator dari Kelengkapan Sarana dan Prasarana) dan ketepatan jenis reward (indikator dari Sistem Reward and Punishment).

3. Sistem reward and punishment masih belum dapat diterapkan secara konsisten dikarenakan berbagai kendala yang muncul dalam implementasinya.

4. Pemberian dispensasi pada Tahun Anggaran 2017 masih cukup tinggi membutuhkan langkah penyesuaian agar kebijakan penyusunan RPD Harian dapat dilaksanakan secara lebih baik.

\subsection{Saran}

1. Satker $\mathrm{K} / \mathrm{L}$ perlu terus meningkatkan Kualitas SDM pengelola keuangannya khususnya terkait pegawai yang mengelola RPD Harian. Berdasarkan hasil kuisioner, upaya yang masih dapat ditingkatkan oleh Satker K/L adalah dengan melakukan 
pemberian insentif yang memadai kepada pegawai yang mengelola RPD Harian antara lain berupa kesempatan pendidikan dan pelatihan dan pemberian insentif finansial/keuangan.

2. KPPN perlu menerapkan Sistem Reward and Punishment secara lebih konsisten sesuai dengan PMK Nomor 277/PMK.05/2014 sehingga dapat memacu Satker K/L untuk menyusun RPD Harian dengan lebih akurat. Bentuk reward yang paling diinginkan oleh mayoritas Satker K/L adalah pemberian layanan prioritas bebas antrian di KPPN secara kontinyu sedangkan bentuk punishment yang paling diinginkan oleh mayoritas Satker K/L adalah berupa penolakan SPM oleh KPPN dimana kedua hal tersebut sudah sesuai dengan bentuk reward and punishment yang diatur dalam PMK Nomor 277/PMK.05/2014.

3. KPPN perlu terus secara selektif dalam memberikan dispensasi kepada Satker K/L sehingga dapat memacu Satker K/L untuk menyusun RPD Harian secara akurat. Kanwil Ditjen Perbendaharaan dan KPPN juga perlu terus melakukan proses edukasi kepada Satker K/L tentang urgensi penyusunan RPD Harian bagi pengelolaan likuiditas kas pemerintah sehingga pada akhirnya semua Satker K/L memiliki persepsi yang sama terkait urgensi perencanaan kas Pemerintah dapat menjalankan kebijakan penyusunan RPD Harian dengan lebih baik.

4. Tingginya pengajuan dispensasi dapat diatasi dengan pengaturan waktu pencairan SPM tanpa RPD Harian secara lebih terkontrol dalam bentuk adanya rentang waktu pencairan sebagaimana SPM dengan RPD Harian. Dengan demikian tingginya volume dispensasi tidak mengganggu pengaturan likuiditas harian oleh Direktorat PKN.

\section{IMPLIKASI DAN KETERBATASAN}

\subsection{Implikasi Penelitian}

Implikasi penelitian ini dari aspek praktis diharapkan dapat memberikan manfaat bagi Direktorat PKN, Kanwil Ditjen Perbendaharaan, KPPN dan Satker K/L dalam ranah implementasi kebijakan perencanaan kas Pemerintah Pusat terutama terkait upaya peningkatan akurasi RPD Harian yang disusun oleh Satker K/L.
Dari aspek teoritis dan keilmuan diharapkan dapat menjadi pelengkap literatur terkait topik perencanaan kas Pemerintah dan dapat digunakan sebagai pijakan bagi penelitian berikutnya dalam topik sejenis.

\subsection{Keterbatasan Penelitian}

Penelitian ini hanya terbatas pada implementasi kebijakan perencanaan kas yang dilaksanakan oleh Satker K/L dalam bentuk penyusunan dan penyampaian RPD Harian Satker K/L dan tidak termasuk implementasi yang dilaksanakan oleh KPPN, Direktorat PKN dan Tim CPIN. Penyusunan Rencana Penarikan Dana pada Satker K/L yang diteliti oleh penulis juga hanya difokuskan pada penyusunan RPD Harian dan tidak termasuk RPD Bulanan serta Rencana Penerimaan dan Pembiayaan Satker K/L. Selain itu, penelitian ini juga hanya dilakukan pada seluruh Satker K/L yang mengajukan RPD Harian pada Tahun Anggaran 2017 dalam lingkup pembayaran KPPN Jakarta II.

Dengan sudah diimplementasikannya penyempurnaan atas PMK Nomor 277/PMK.05/2014 yaitu PMK Nomor 197/PMK.05/2017 mulai Tahun Anggaran 2018, penulis menyarankan untuk penelitian dengan topik sejenis berikutnya agar berpedoman pada PMK terbaru tersebut dengan pemilihan obyek penelitian yang lebih luas dan periode penelitian yang lebih panjang sehingga dihasilkan karakteristik hasil penelitian yang lebih beragam.

\section{PENGHARGAAN (ACKNOWLEDGEMENT)}

Penelitian ini didanai oleh Lembaga Pengelola Dana Pendidikan (LPDP) Kementerian Keuangan. Selain itu, penelitian ini dapat diselesaikan berkat bantuan rekan-rekan Direktorat Pengelolaan Kas Negara, KPPN Jakarta II, Satker K/L lingkup KPPN Jakarta II serta pihak-pihak lain yang tidak dapat kami sebutkan satu per satu.

\section{REFERENSI}

Basri, S. (2012). Uji validitas dan reliabilitas instrumen penelitian dengan SPSS. Diakses 11 Maret 2018 dari http://setabasri01. blogspot.co.id/2012/04/uji-validitasdan-reliabilitas-item.html

Ghozali, I. (2016). Aplikasi analisis multivariete edisi 8. Semarang: Badan Penerbit Universitas Diponegoro. 
Gujarati, D. (2003). Ekonometri dasar, terjemahan (Sumarno Zain, Penerjemah). Jakarta: Erlangga.

Hair et al. (2010). Multivariate data analysis, seventh edition. New York: Prentice Hall.

Undang-undang Nomor 17 Tahun 2003 tentang Keuangan Negara. Jakarta: Republik Indonesia.

Undang-Undang Nomor 1 Tahun 2004 tentang Perbendaharaan Negara. Jakarta: Republik Indonesia.

Undang-Undang Nomor 18 Tahun 2016 tentang Anggaran Pendapatan dan Belanja Negara Tahun 2017. Jakarta: Republik Indonesia.

Indriasari, D., \& Nahartyo, E. (2008). Pengaruh kapasitas sumber daya manusia, pemanfaatan teknologi informasi dan pengendalian intern akuntansi terhadap nilai informasi pelaporan keuangan pemerintah daerah. Simposium Nasional Akuntansi 11 Pontianak.

Ivancevich, K., \& Matteson. (2006). Perilaku manajemen dan organisasi (Gina Gania, Penerjemah). Jakarta: PT. Erlangga.

Izzati, K.N. (2011). Pengaruh gaya kepemimpinan dan kualitas sumber daya manusia terhadap penerapan anggaran berbasis kinerja badan layanan umum (Studi pada BLU Universitas Diponegoro Semarang). Skripsi. Semarang: Universitas Diponegoro.

Kosasi, S. (2014). Pengukuran kinerja web brinet system dengan metode it balanced scorecard. Jurnal Buana Informatika, 6(1), 1-10

Lienert, I. (2009). Modernizing cash management, working paper. International Monetary Fund.

$\mathrm{Mu}, \mathrm{Y}$. (2006). Government cash management: good practice \& capacity-building framework, working paper. World Bank: Financial Sector Discussion Series.

Mulyani, S. (2008). Analisis pengaruh faktorfaktor kecerdasan emosi terhadap komunikasi interpersonal perawat dengan pasien di unit rawat inap RSJD Dr. Amino Gondohutomo Semarang tahun 2008. Thesis. Universitas Diponegoro Semarang.

Munir, M. M. M. (2016). A logistic regression model of ustomer satisfaction of e-banking service quality in Bangladesh. Account and Financial Management Journal, 1(3), 124-
140.

Muthohar, A. (2012). Faktor-faktor utama yang mempengaruhi efektivitas perencanaan kas pada satuan kerja-satuan kerja $K / L$ dalam lingkup wilayah pembayaran KPPN Jakarta II. Tesis Tidak Dipublikasikan. MPKP-FEUI.

Nawawi, H. (2005). Manajemen sumber daya manusia untuk bisnis yang kompetitif. Yogyakarta: Universitas Gajah Mada.

Nugroho, B. (2006). Reward and punishment. Departemen Pekerjaan Umum: Buletin Karya Cita.

Peraturan Pemerintah Nomor 39 Tahun 2007 tentang Pengelolaan Uang Negara/Daerah. Jakarta: Republik Indonesia.

Peraturan Menteri Keuangan (PMK) Nomor 192/PMK.05/2009 tentang Perencanaan Kas. Jakarta: Republik Indonesia.

Peraturan Menteri Keuangan Nomor 277/PMK.05/2014 tentang Rencana Penarikan Dana, Rencana Penerimaan Dana dan Perencanaan Kas. Jakarta: Republik Indonesia.

Rahardja, P., \& Manurung, M. (2004). Teori ekonomi mikro edisi kedua. Jakarta: Lembaga Penerbit Fakultas Ekonomi UI.

Robbins, S. P. (2006). Perilaku organisasi (Drs. Benjamin Molan, Penerjemah). Klaten: PT. Intan Sejati.

Santoso, S. (2016). Statistik multivariat dengan SPSS. Jakarta: Kompas Gramedia.

Sembiring, F. L. (2013). Pengaruh kualitas sumber daya manusia, pemanfaatan teknologi informasi dan sistem pengendalian intern terhadap keandalan dan ketepatwaktuan pelaporan keuangan pemerintah (studi empiris pada pemerintah Kota Padang). Jurnal Akuntansi.

Storkey, I. (2003). Government Cash Management and Treasury Management Reform. Asian Development Bank: Governance Brief

Sukirno, S. (1994). Pengantar teori ekonomi makro. Jakarta: Raja Grafindo.

Timpe, A. D. (1992). The art and science of business management performance. Mumbai: Jaico Publishing House

Utrech, E. (1960). Pengantar hukum administrasi negara Indonesia, Cetakan ke 4. Jakarta: 
Ichtiar Baru.

Veithzal, R. (2005). Manajemen sumber daya manusia untuk perusahaan. Jakarta: PT. Raja Grafindo Persada

Williams, M. (2004). Government cash management: good and bad practices. Oxford Policy Management

Williams, M. (2009). Government Cash Management: International Practice, working paper. Oxford Policy Management. 